\title{
Element Concentrations in a Unionid Mussel (Anodonta woodiana) at Different Life Stages
}

\section{Chen, Xiubao}

Wuxi Fisheries College, Nanjing Agriculture University : Key Laboratory of Ecological Environment and Resources of Inland Fisheries, Freshwater Fisheries Research Center, Chinese Academy of Fishery Sciences

Yang, Jian

Wuxi Fisheries College, Nanjing Agriculture University : Key Laboratory of Ecological Environment and Resources of Inland Fisheries, Freshwater Fisheries Research Center, Chinese Academy of Fishery Sciences

Liu, Hongbo

Key Laboratory of Ecological Environment and Resources of Inland Fisheries, Freshwater Fisheries Research Center, Chinese Academy of Fishery Sciences

\section{Su, Yaping}

Key Laboratory of Ecological Environment and Resources of Inland Fisheries, Freshwater Fisheries Research Center, Chinese Academy of Fishery Sciences

他

ht tps://doi.org/10.5109/22061

出版情報 : 九州大学大学院農学研究院紀要. 57 (1)，pp.139-144，2012-02. Faculty of Agriculture， Kyushu University

バージョン :

権利関係 : 


\title{
Element Concentrations in a Unionid Mussel (Anodonta woodiana) at Different Life Stages
}

\author{
Xiubao CHEN ${ }^{1,2}$, Jian YANG ${ }^{1,2, *}$, Hongbo LIU', \\ Yaping $\mathrm{SU}^{2}$, Lei SUN ${ }^{1,2}$ and Yuji OSHIMA ${ }^{3}$
}

\author{
Aquatic Biomonitoring and Environmental Laboratory, Department of Bioscience and Biotechnology, \\ Faculty of Agriculture, Kyushu University, Fukuoka 812-8581, Japan \\ (Received October 31, 2011 and accepted November 9, 2011)
}

\begin{abstract}
The 'background' levels of 18 elements (Na, Mg, Al, K, Ca, Cr, Mn, Fe, Co, Ni, Cu, Zn, As, Se, Mo, Ag, $\mathrm{Cd}$, and $\mathrm{Tl}$ ) were measured in unionid mussels (Anodonta woodiana) at three different life stages (i.e., glochidia-whole body, juveniles and gravid adults-whole soft tissue). Field-collected adult mussels were cultured in experiment ponds for one year before used for tissue collection. Matured glochidia were collected from the adults for the element measurement and the culture of the juvenile mussels. The results of principal component analysis of the element concentrations indicated a significant life stage-dependent variation of element accumulation. The concentrations of $\mathrm{Ca}, \mathrm{Fe}, \mathrm{Zn}, \mathrm{As}, \mathrm{Cd}, \mathrm{Ni}$, and $\mathrm{Mn}$ were generally higher in the adult mussels than those in the juvenile mussels. However, several elements (e.g., $\mathrm{Co}, \mathrm{Cu}, \mathrm{Mo}, \mathrm{Ag}$ ) were significantly higher in the juveniles than those in the adults. Manganese appeared to be accumulated at high concentration in all three life stages. The background residue concentrations of heavy metals and toxic elements in the artificially produced mussels were very low, while that contaminated As in gravid adults was still obviously high, suggesting that the formers will be potentially more suitable to be used as the bioindicators for the corresponding elements by wild transplantation or laboratory exposure study rather than the gravid adults.
\end{abstract}

Key words: Anodonta woodiana, element, glochidia, gravid adults, juveniles

\section{INTRODUCTION}

Unionid mussels are useful in monitoring temporal and spatial trends of a wide range of persistent pollutants in aquatic environments due to many advantages e.g., a wide geographical distribution, sedentary life style, long lifespan, tolerance to a wide range of contaminants, poor metabolic capacity for pollutants, correlation of pollutant content between organism and habitat, adequate tissue for analyses (Tanabe and Subramanian, 2006). A unionid mussel (Anodonta woodiana) has been used as a unique bioindicator for 'Freshwater Mussel Watch' research in the Taihu Lake of China (Yang et al., 2005) to assess the contamination of organotins (Yang et al., 2008), organochlorines (Bian et al., 2009) and heavy metals (Liu et al., 2010).

A. woodiana is a worldwide-distributed freshwater mussel (Watters, 1997). In China, this species is a traditional edible mussel and its liposome-incorporated aqueous extracts can be potentially applied as a natural antitumor and immunomodulator formulation (Liu et al., 2008). Mussels are filter feeders and therefore clean water by reducing algae, particles and toxic materials in the water column (Kurnia et al., 2010). The life history

\footnotetext{
1 Wuxi Fisheries College, Nanjing Agriculture University, Wuxi, 214081

2 Key Laboratory of Ecological Environment and Resources of Inland Fisheries, Freshwater Fisheries Research Center, Chinese Academy of Fishery Sciences, Wuxi, 214081

3 Aquatic Biomonitoring and Environmental Laboratory, Department of Bioscience and Biotechnology, Faculty of Agriculture, Kyushu University, Fukuoka 812-8581, Japan

* Corresponding author (E-mail: jiany@ffrc.cn)
}

of $A$. woodiana, like most unionoids, includes release of sperm by adult males, uptake of sperm by females, fertilization of ova, release of glochidia from females, and attachment of glochidia to a suitable host fish for transformation into juveniles (Cope et al., 2008; Dudgeon and Morton, 1983; 1984).

The utilization of mussel-based Mussel Watch monitoring (both passive biomonitoring and active biosurveillance) is generally dependent on field-collected mussels (Andral et al., 2004). However, it is difficult to ensure the collection of mussel samples (mainly soft tissue) with similar age/size. This limitation can significantly influence the results of the bioaccumulation of heavy metals and other elements due to different age or size (MetcalfeSmith et al., 1996). Moreover, wild mussels are sometimes rare, or even absent in study locations (Andral et al., 2007; Williams et al., 1993). Herein a captive breeding population of $A$. woodiana (including glochidia, juveniles, and gravid adults) has been established by artificial propagation techniques in our research laboratory. The cultured mussels can be subsequently transplanted to field with the same source, age, stage of sexual maturity (Andral et al., 2004), and low background levels of heavy metals for pollution monitoring.

There have been numerous reports of heavy metals and other elements in adult mussels (e.g., Ferrington et al., 1983; Naimo 1995; Ravera et al., 2003a; 2003b; 2005; Usero et al., 2005) since the Mussel Watch concept was proposed by Goldberg (1975). However, few of studies have been reported on element bioavailability and bioaccumulation in mussels at the different life stages (Cravo et al., 2004). These data from different life stages provide important 'background' levels for interpretation the 
monitoring results using mussels as the bioindicators (Scanes and Roach, 1999). In the present study, we assessed the level and dynamics of 18 elements ( $\mathrm{Na}, \mathrm{Mg}$, $\mathrm{Al}, \mathrm{K}, \mathrm{Ca}, \mathrm{Cr}, \mathrm{Mn}, \mathrm{Fe}, \mathrm{Co}, \mathrm{Ni}, \mathrm{Cu}, \mathrm{Zn}, \mathrm{As}, \mathrm{Se}, \mathrm{Mo}, \mathrm{Ag}, \mathrm{Cd}$, and $\mathrm{Tl}$ ) in $A$. woodianain whole body of glochidia and whole soft tissue of juveniles and gravid adults cultured in our research laboratory.

\section{MATERIALS AND METHODS}

\section{Sampling}

Glochidia, juveniles (J1, 1-month old; J2, 3.5-month old) and gravid adults of $A$. woodiana were collected from an experiment pond of Nanquan Aquatic Base, Freshwater Fisheries Research Center, Chinese Academy of Fishery Sciences (NFC) from May 2008 to July 2009. The adults were initially collected from Taihu Lake, which is the third largest freshwater lake in China, and cultured in the pond of the NFC for 1 year before used to produce glochidia and the J1 juveniles and J2 juveniles. Once collected, the specimens were depurated for more than $72 \mathrm{~h}$ to eliminate gut contents. After a preliminary shell clean-up, the biometric parameters of each bivalve were measured (Table 1). The soft tissues were separated from the shells with a stainless steel scalpel. The matured glochidia (Table 1) were removed from marsupiums of gravid adults. All samples were frozen and maintained at $-20^{\circ} \mathrm{C}$ pending processing. For analysis, the samples were defrosted and washed repeatedly with Milli-Q water (Millipore Corp., USA, with resistivity: 18.2 $\mathrm{M} \Omega \bullet \mathrm{CM}$ ). Because of the small body size, the glochidia were divided randomly into four equal analysis samples. Likewise, the soft tissues of the J1 juveniles and J2 juveniles were divided randomly into three equal analysis samples, respectively. As for the gravid adults, total soft tissues from four adults were sampled individually for chemical analysis. The samples of glochidia and soft tissues of juvenile and adult mussels were weighed and dried firstly at $80^{\circ} \mathrm{C}$ for $24 \mathrm{~h}$. Each dried sample was pulverized individually in an agate mortar and the resulting homogeneous fine powders stored for subsequent analysis.

\section{Element analysis}

Element concentrations of glochidia and gravid adults were measured according to a method modified from the method described in Liu et al. (2010). Briefly, approximately $0.1 \mathrm{~g}$ of dried sample was weighed in a Teflon tube (San'ai Science Co., Japan) to which $1.5 \mathrm{~mL}$ of purified nitric acid was added. After pre-digestion at room temperature overnight, the tubes were treated in a microwave oven for $7 \mathrm{~min}$ at $230 \mathrm{~W}$, and this procedure was repeated twice. The resultant solution was diluted to a final volume of $30 \mathrm{~mL}$ with Milli-Q water and transferred to an acid washed polypropylene tube.

The concentrations of elements of J1 juveniles and J2 juveniles were determined following the procedure described by Ye et al. (2011). Simply, each dry sample $(0.1 \pm 0.005 \mathrm{~g})$ was placed into a Teflon digestion tube, and $10 \mathrm{~mL}$ of purified $\mathrm{HNO} 3$ was added. All the samples were then digested for $10 \mathrm{~min}$ at $120^{\circ} \mathrm{C}, 15 \mathrm{~min}$ at $170^{\circ} \mathrm{C}$, and a further $15 \mathrm{~min}$ at $170^{\circ} \mathrm{C}$ using a microwave digestion system (ETHOS A T260, Milestone Inc., Italy), and the resultant solutions were diluted to $200 \mathrm{~mL}$ with Milli-Q water.

Concentrations of $\mathrm{Na}, \mathrm{Mg}, \mathrm{Al}, \mathrm{K}, \mathrm{Ca}, \mathrm{Cr}, \mathrm{Mn}, \mathrm{Fe}, \mathrm{Co}$, $\mathrm{Ni}, \mathrm{Cu}, \mathrm{Zn}$, As, Se, Mo, Ag, Cd, and $\mathrm{Tl}$ were analyzed by an Agilent 7500ce Inductive Coupled Plasma - Mass Spectrometry (ICP-MS, Agilent, USA). Matrix-effects and instrumental drift of the ICP-MS were corrected by $\mathrm{Li}, \mathrm{Sc}, \mathrm{Ge}, \mathrm{Y}, \mathrm{In}$, and $\mathrm{Bi}$ as the internal standard. Recoveries of metal spiked into water samples $(n=3)$ and analyzed by quantitative ICP-MS ranged from 81.3 to $133.7 \%$. All concentration data were expressed as $\mu \mathrm{g} / \mathrm{g}$ dry weight.

\section{Data analysis}

Statistical analyses were performed using the program SPSS V16.0 (SPSS Inc., USA). A one-way analysis of variance (ANOVA) test was applied to determine the differences between mussel element concentrations at different life stages. A significance level was set up at $P<0.05$. Principal components analysis (PCA) was conducted to evaluate the comprehensive element accumulation pattern of each mussel at different life stages.

\section{RESULTS AND DISCUSSION}

In glochidia of $A$. woodiana, $\mathrm{Na}, \mathrm{Mg}, \mathrm{Al}, \mathrm{K}, \mathrm{Ca}, \mathrm{Cr}$, $\mathrm{Mn}, \mathrm{Fe}, \mathrm{Ni}, \mathrm{Cu}, \mathrm{Zn}, \mathrm{As}, \mathrm{Se}$, and Mo were detected while Co, Ag, Cd, and $\mathrm{Tl}$ were not detected (Table 2). Essential $\mathrm{Ca}$ and $\mathrm{Na}$ were the most prominent elements detected, whereas toxic $\mathrm{Cr}, \mathrm{Ni}$, As showed the lowest levels. The concentrations of detected elements generally decreased in the order $\mathrm{Ca}>\mathrm{Na}>\mathrm{Mn}>\mathrm{K}>\mathrm{Mg} \approx$

Table 1. Biometry data (mean \pm SD) of glochidia, juveniles and gravid adults of Anodonta woodiana

\begin{tabular}{|c|c|c|c|c|c|c|}
\hline Life stage & $\begin{array}{c}\text { Age } \\
\text { (Month) }\end{array}$ & $\begin{array}{c}\text { No. of } \\
\text { individuals }\end{array}$ & $\begin{array}{l}\text { Shell length } \\
(\mathrm{mm})\end{array}$ & $\begin{array}{l}\text { Shell width } \\
\text { (mm) }\end{array}$ & $\begin{array}{l}\text { Shell height } \\
\text { (mm) }\end{array}$ & $\begin{array}{l}\text { No. of samples for } \\
\text { chemical analysis }\end{array}$ \\
\hline Glochidia (G) & / & l & $0.257 \pm 0.008^{\mathrm{a}}$ & / & $0.290 \pm 0.01^{\mathrm{a}}$ & 4 \\
\hline Juveniles (J1) & 1 & 87 & $17.5 \pm 2.0$ & $4.3 \pm 0.7$ & $8.9 \pm 1.1$ & 3 \\
\hline Juveniles (J2) & 3.5 & 12 & $35.8 \pm 2.7$ & $12.1 \pm 1.7$ & $20.3 \pm 1.7$ & 3 \\
\hline Gravid Adults (GA) & 36 & 4 & $118.7 \pm 9.7$ & $47.9 \pm 4.1$ & $75.6 \pm 3.4$ & 4 \\
\hline
\end{tabular}

a Thirty glochidia were measured randomly. 
Table 2. Concentrations of various elements in glochidia, and soft tissues of juveniles, and gravid adults of Anodonta woodiana ( $\mu$ g/g dry weight). nd, not detected. The mean data with different superscripts in the same row (except for those of Glochidia) are significantly different $(P<0.05)$ following an one-way analysis of variance (ANOVA) test

\begin{tabular}{|c|c|c|c|c|c|c|c|c|}
\hline \multirow{3}{*}{ Element } & \multirow{2}{*}{\multicolumn{2}{|c|}{ Glochidia }} & \multicolumn{4}{|c|}{ Juveniles } & \multirow{2}{*}{\multicolumn{2}{|c|}{ Gravid Adults }} \\
\hline & & & \multicolumn{2}{|c|}{ 1-month-age juveniles ( J1) } & \multicolumn{2}{|c|}{ 3.5-month-age juveniles ( J2) } & & \\
\hline & Mean \pm SD & Range & Mean \pm SD & Range & Mean \pm SD & Range & Mean \pm SD & Range \\
\hline $\mathrm{Na}$ & $1819 \pm 610$ & $1314-2706$ & $164 \pm 48^{\mathrm{a}}$ & $114-209$ & $589 \pm 64^{\mathrm{b}}$ & $537-660$ & $1055 \pm 113^{c}$ & $957-1172$ \\
\hline $\mathrm{Mg}$ & $183 \pm 77$ & $120-294$ & $825 \pm 40$ & $786-866$ & $773 \pm 69$ & $710-846$ & $900 \pm 122$ & $727-1012$ \\
\hline $\mathrm{Al}$ & $60 \pm 15$ & $40-76$ & $328 \pm 210$ & $198-570$ & $525 \pm 564$ & $106-1167$ & $62 \pm 33$ & $36-109$ \\
\hline $\mathrm{K}$ & $232 \pm 263$ & $64-623$ & nd & / & $210 \pm 54^{\mathrm{a}}$ & $148-243$ & $1622 \pm 235^{b}$ & $1363-1933$ \\
\hline $\mathrm{Ca}$ & $438625 \pm 66226$ & $343700-487100$ & $24264 \pm 1563^{\mathrm{a}}$ & 23310-26068 & $16415 \pm 1083^{\mathrm{b}}$ & $15233-17360$ & $29963 \pm 13100^{\mathrm{ab}}$ & $15120-43250$ \\
\hline $\mathrm{Cr}$ & $0.5 \pm 0.5$ & nd-1.0 & nd & I & nd & I & nd & / \\
\hline Mn & $417 \pm 48$ & 369-482 & $3479 \pm 194$ & 3335-3699 & $2933 \pm 241$ & $2783-3211$ & $3560 \pm 1218$ & $2076-4659$ \\
\hline $\mathrm{Fe}$ & $180 \pm 27$ & $164-221$ & $563 \pm 82$ & 509-657 & $753 \pm 794$ & $264-1670$ & $1089 \pm 296$ & 840-1486 \\
\hline Co & nd & & $25 \pm 0.7^{\mathrm{a}}$ & $24-25$ & $25 \pm 0.1^{\mathrm{a}}$ & 24.9-25.2 & nd & I \\
\hline $\mathrm{Ni}$ & $0.9 \pm 0.4$ & $0.4-1.2$ & nd & I & nd & I & $0.4 \pm 0.1^{\mathrm{b}}$ & $0.3-0.5$ \\
\hline $\mathrm{Cu}$ & $17 \pm 3.3$ & $15-22$ & $29 \pm 0.7^{\mathrm{a}}$ & 28-30 & $28 \pm 0.2^{\mathrm{a}}$ & $27.8-28.1$ & $13 \pm 5.9^{b}$ & $8.4-21$ \\
\hline $\mathrm{Zn}$ & $78 \pm 15$ & 64-99 & $234 \pm 11^{\mathrm{a}}$ & $225-246$ & $144 \pm 12^{\mathrm{a}}$ & $132-156$ & $606 \pm 208^{\mathrm{b}}$ & $327-817$ \\
\hline As & $5.0 \pm 2.3$ & $3.3-8.2$ & nd & I & nd & I & $8.2 \pm 0.8^{b}$ & 7.3-9.3 \\
\hline $\mathrm{Se}$ & $0.8 \pm 0.2$ & $0.7-1.1$ & nd & I & nd & I & $2.6 \pm 0.4^{\mathrm{b}}$ & $2.1-3.0$ \\
\hline Mo & $0.02 \pm 0.03$ & nd -0.06 & $28 \pm 0.7^{\mathrm{a}}$ & $27-29$ & $28 \pm 0.3^{\mathrm{a}}$ & $28-28.5$ & $0.08 \pm 0.06^{\mathrm{b}}$ & $0.02-0.2$ \\
\hline $\mathrm{Ag}$ & nd & I & $29 \pm 0.8^{\mathrm{a}}$ & $28-30$ & $29 \pm 0.3^{\mathrm{a}}$ & $29-30$ & nd & I \\
\hline $\mathrm{Cd}$ & nd & / & nd & I & nd & I & $0.7 \pm 0.4^{\mathrm{b}}$ & $0.3-1.4$ \\
\hline $\mathrm{Tl}$ & nd & I & $1.6 \pm 0.05^{\mathrm{a}}$ & $1.6-1.7$ & $1.6 \pm 0.01^{\mathrm{a}}$ & $1.6-1.7$ & nd & \\
\hline
\end{tabular}

$\mathrm{Fe}>\mathrm{Al}>\mathrm{Zn}>\mathrm{Cu}>\mathrm{As}>\mathrm{Ni} \approx \mathrm{Se}>\mathrm{Cr}>\mathrm{Mo}$. Glochidia, consist of shell valves with hook, adductor muscles, mantle, and byssus (Fisher and Dimock, 2002), are the unique larval life stage of most freshwater mussels in the family Unionidae (Haag and Warren, 1999). Brooding through matrotrophy by adult mussels provides nutritional and physiological support for larvae within the marsupium (Watters, 2007), and isolates them from potentially unfavorable water habitats (Schwartz and Dimock, 2001). However, to our knowledge, no data on the maternal-glochidial transfer and bioaccumulation of trace elements are available in mussel at this stage. Our findings that the bioavailability of $\mathrm{Ca}, \mathrm{Na}, \mathrm{Mn}, \mathrm{K}, \mathrm{Mg}, \mathrm{Fe}$, $\mathrm{Al}, \mathrm{Zn}, \mathrm{Cu}, \mathrm{Ni}, \mathrm{Se}, \mathrm{Cr}, \mathrm{Mo}$, and As to glochidia of $A$. woodiana suggested maternal-glochidial transfer of not only essential major elements (e.g., Ca, Na, K, Mg, Fe) and trace elements (e.g., Mn, Zn, Cu, Se, Mo), but also nonessential (e.g., $\mathrm{Al}$ ) and toxic elements (e.g., As, Cr, $\mathrm{Ni}$ ). Therefore, the aforementioned marsupium might not protect glochidia against the transfer and exposure to $\mathrm{As}, \mathrm{Cr}$, or Ni when parent mussels are exposed to these toxic elements. Noteworthily, essential Ca and $\mathrm{Na}$ were the most prominent elements in glochidia of this study. Calcium is the primary component in mollusc larval shell (Jacob et al., 2008; Weiss et al., 2002) and involved in the structure of the muscular system and controls essential processes like muscle contraction and cell growth (Belitz et al., 2009). Sodium mostly presents as an extracellular constituent and activates some enzymes, such as amylase (Belitz et al., 2009).
In the soft tissues of J1 juveniles, the mean concentrations of $\mathrm{Ca}$ and $\mathrm{Mn}$ were much higher than those of any other elements (Table 2). Chromium, Ni, As, and Cd were not detected and the concentrations of detected elements generally decreased in the order $\mathrm{Ca}>\mathrm{Mn}>\mathrm{Mg}>$ $\mathrm{Fe}>\mathrm{Al}>\mathrm{Zn}>\mathrm{Na}>\mathrm{Ag} \approx \mathrm{Cu}>\mathrm{Mo}>\mathrm{Co}>\mathrm{Tl}>\mathrm{K} \approx \mathrm{Cr}$ $\approx$ Se (Table 2). In the soft tissues of J2 juveniles, Ca and Mn concentrations were higher than those of any other elements. Likewise in the soft tissues of J1 juveniles, toxic $\mathrm{Cr}, \mathrm{Ni}, \mathrm{As}$, and Cd were not detected. The concentration order for remaining elements generally decreased as $\mathrm{Ca}>\mathrm{Mn}>\mathrm{Mg} \approx \mathrm{Fe}>\mathrm{Na}>\mathrm{Al}>\mathrm{K}>\mathrm{Zn} \approx \mathrm{Ag} \approx \mathrm{Mo} \approx$ $\mathrm{Cu} \approx \mathrm{Co}>\mathrm{Tl}$ (Table 2 ). Therefore, the bioaccumulation pattern of elements could vary during organogenic changes in juveniles of $A$. woodiana, probably relating to some special reasons, e.g., the feeding behavior. By an observation on the morphology and the sequence of organogenesis from juvenile to adult in a similar pearl mussel Hyriopsis myersiana, Kovitvadhi et al. (2007) found that the ciliary mechanisms around the foot, the mantle, gill, and those on the papillae around the opening of the incurrent siphon were the main feeding behaviors of selective food intake for the 0-40 day-glochidium and 40->80 day-juvenile, respectively.

In contrast to those in glochidia and juveniles, $\mathrm{Ca}$, $\mathrm{Mn}, \mathrm{K}, \mathrm{Fe}$ and Na were found at higher concentrations than those of any other elements in the soft tissues of gravid adults, while $\mathrm{Cr}$, Co, Ag, and Tl were not detected. It is noteworthy that toxic elements $\mathrm{Ni}$, As, and Cd were detected (Table 2). The concentration order of detected 
element decreased was $\mathrm{Ca}>\mathrm{Mn}>\mathrm{K}>\mathrm{Fe} \approx \mathrm{Na}>\mathrm{Mg}>$ $\mathrm{Zn}>\mathrm{Al}>\mathrm{Cu}>\mathrm{Se}>\mathrm{Cd}>\mathrm{Ni}>\mathrm{Mo}$ (Table 2). Adult bivalve molluscs have strong ability to filter large volumes of water and obtain food (e.g., detritus, zooplankton, bacteria, algae) principally by filter feeding (Christian and Smith, 2004; Naimo, 1995). As a result, both diet and water can contribute to element accumulation in tissues (Hédouin et al., 2007; Pernice et al., 2009; Pynnönen, 1991; Wang and Fisher, 1996; 1999a; b), and the diet is considered as a major route (Hédouin et al., 2007).

Principal components analysis (PCA) of the element concentrations in the present study was conducted to investigate the comprehensive element accumulation patterns of the mussels at different life stages. The obviously separated scatter plots of scores indicated that there was a significant life history stage-dependent variation of element accumulation among different life stages of the mussel (especially those of glochidia and gravid adults; Fig. 1).

A comparison is made with the mean element concentrations in soft tissues of Anodonta mussels at different size in the present study and literature (Table 3). $\mathrm{Ca}, \mathrm{Fe}, \mathrm{Zn}, \mathrm{As}, \mathrm{Cd}, \mathrm{Ni}, \mathrm{Mn}$ in A. woodiana and other two Anodonta mussels were generally higher in the adults than those in the juvenile mussels. However, several elements could obviously higher in the latter than those in the former (e.g., Co, $\mathrm{Cu}, \mathrm{Mo}, \mathrm{Ag}$ ). It is noteworthy that Mn was extremely high concentration in every stage individuals of $A$. woodiana in the present study (Table 2), and the freshwater Anodonta mussels in previous literatures (Liu et al., 2010; Table 3), which was much higher than that of any other elements except for $\mathrm{Ca}$, probably due to that Mn has a special nutritional/physiological function for Anodonta mussels, or that the higher concentrations $(10-10000 \mu \mathrm{g} / \mathrm{L})$ of dissolved Mn in freshwater environments (Reimer, 1999). Wenchuan et al. (2001) reported that $\mathrm{Mn}$ in surface sediments of the Taihu Lake was as high as 360-1500 mg/Kg dry weight.

Table 4 shows the 'background' concentrations of some important heavy metals and toxic elements in tissues of the juveniles and gravid adults of $A$. woodiana mussels from the present study. All element concentrations in the juveniles were far below the residue limits of China, EC and FAO (Table 4) with two exceptions. Zinc concentrations in the adults were within or slightly higher than the range of $\mathrm{FAO}$; As concentration in the adults ( $1.3 \mu \mathrm{g} / \mathrm{g}$ wet weight) exceeded the limit of China

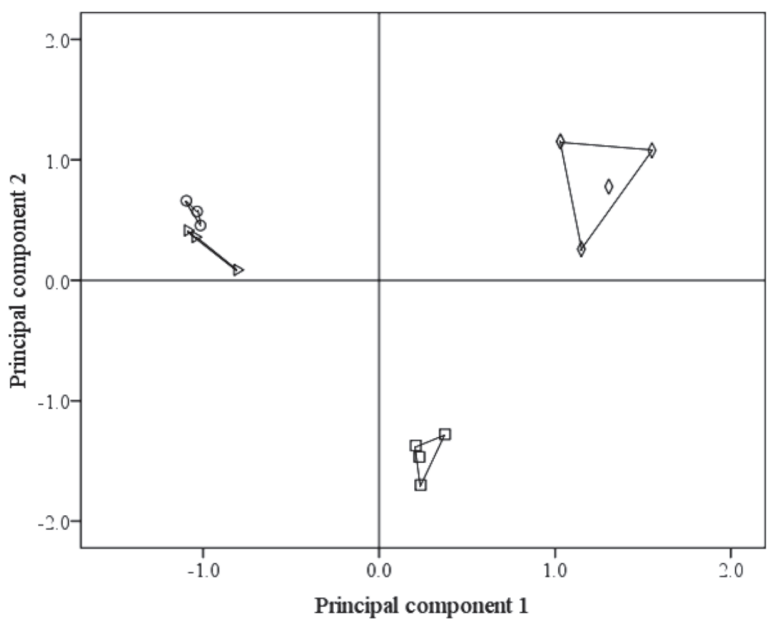

Fig. 1. Scatter plots for scores of principal component analysis in the different stages of Anodonta woodiana. Glochidia (square); J1 juveniles (circle); J2 juveniles (triangle); gravid adults (diamond).

Table 3. Comparison of element concentrations ( $\mu \mathrm{g} / \mathrm{g}$ dry weight) in soft tissues of Anodonta mussels from different geographical areas

\begin{tabular}{|c|c|c|c|c|c|c|c|c|c|c|c|c|c|c|c|c|}
\hline Location & $\begin{array}{l}\text { size }^{\mathrm{a}} \\
(\mathrm{mm})\end{array}$ & $\mathrm{Ca}$ & $\mathrm{Cr}$ & $\mathrm{Mn}$ & $\mathrm{Fe}$ & Co & $\mathrm{Ni}$ & $\mathrm{Cu}$ & $\mathrm{Zn}$ & As & Se & Mo & $\mathrm{Ag}$ & $\mathrm{Cd}$ & $\mathrm{Tl}$ & References \\
\hline \multicolumn{17}{|l|}{ Anodonta woodiana } \\
\hline $\mathrm{NFC}^{\mathrm{b}}$, China & 17.5 & 24264 & nd & 3479 & 563 & 25 & nd & 29 & 234 & nd & nd & 28 & 29 & nd & 1.6 & This work \\
\hline $\mathrm{NFC}^{\mathrm{b}}$, China & 35.8 & 16415 & nd & 2933 & 753 & 25 & nd & 28 & 144 & nd & nd & 28 & 29 & nd & 1.6 & This work \\
\hline $\mathrm{NFC}^{\mathrm{b}}$, China & 118.7 & 29963 & nd & 3560 & 1089 & nd & 0.4 & 13 & 606 & 8.2 & 2.6 & 0.08 & nd & 0.7 & nd & This work \\
\hline Sanshandao, Taihu Lake, China & 102.2 & & nd & 11237 & 4287 & nd & nd & 19 & 1252 & 15 & 15 & 0.3 & 0.5 & 22 & & Liu et al. (2010) \\
\hline Mashan, Taihu Lake, China & 97.0 & & nd & 5921 & 2069 & nd & nd & 18 & 677 & 12 & 14 & 0.7 & 0.3 & 23 & & Liu et al. (2010) \\
\hline Huzhou, Taihu Lake, China & 110.8 & & nd & 11886 & 1977 & nd & nd & 0.4 & 661 & 12 & 6.7 & 0.1 & nd & 0.1 & & Liu et al. (2010) \\
\hline Dapu, Taihu Lake, China & 92.6 & & nd & 8328 & 1386 & nd & nd & 8.1 & 912 & 15 & 7.8 & 0.2 & 0.6 & 2.5 & & Liu et al. (2010) \\
\hline \multicolumn{17}{|l|}{ Anodonta cygnea } \\
\hline Ranco Bay, Italy & $65-72$ & 74119 & 0.4 & 11258 & & 1.0 & 5.0 & 34 & 642 & 13 & & 1.0 & & 10 & 0.03 & Ravera et al. (2003) \\
\hline Anzali wetland, Iran & $99-134$ & & & & & & & 0.21 & & & & & & 0.1 & & Pourang et al. (2010) \\
\hline Anzali wetland, Iran & $111-140$ & & & & & & & 0.21 & & & & & & 0.01 & & Pourang et al. (2010) \\
\hline \multicolumn{17}{|l|}{ Anodonta anodonta } \\
\hline Dnieper River, Kiev, Ukraine & $83-88$ & & & & & & $0.26^{\mathrm{c}} / 1.9^{\mathrm{d}}$ & $8.8^{\mathrm{c}} / 36.3^{\mathrm{d}}$ & $140 \mathrm{c} / 489^{\mathrm{d}}$ & & & & & & & Lukashev (2010) \\
\hline Desna River, Chernigov, Ukraine & $92-98$ & & & & & & $0.43^{\mathrm{c}} / 1.1^{\mathrm{d}}$ & $3.6^{c} / 4.7^{\mathrm{d}}$ & $79 \mathrm{c} / 228^{\mathrm{d}}$ & & & & & & & Lukashev (2010) \\
\hline
\end{tabular}

${ }^{a}$ The mean or range values of shell length, ${ }^{b}$ Nanquan Aquatic Base, Freshwater Fisheries Research Center, Chinese Academy of Fishery Sciences, ${ }^{\mathrm{c}}$ In the clean sections,

${ }^{d}$ Downstream near sewage release, nd, not detected. 
Table 4. Comparison of concentrations of some heavy metals and arsenic in the soft tissues of juveniles and gravid adults of Anodonta woodiana in the present study with related national and international limits ( $\mu \mathrm{g} / \mathrm{g}$ wet weight)

\begin{tabular}{|c|c|c|c|c|c|c|}
\hline Element & J1 juveniles ${ }^{\mathrm{a}}$ & J2 juveniles ${ }^{\mathrm{a}}$ & Gravid Adults & China & $\mathrm{EC}^{\mathrm{e}}$ & $\mathrm{FAO}^{\mathrm{f}}$ \\
\hline $\mathrm{Cr}$ & nd & nd & nd & $2.0^{c}$ & & 1 \\
\hline $\mathrm{Cu}$ & $1.0(0.98-1.05)^{\mathrm{b}}$ & $1.85(1.83-1.85)$ & $2.0(1.3-3.3)$ & $50^{\mathrm{d}}$ & & $10-30$ \\
\hline $\mathrm{Zn}$ & $8.2(7.9-8.6)$ & $9.5(8.7-10.3)$ & $94(51-127)$ & & & $40-100$ \\
\hline As & nd & nd & $1.3(1.1-1.4)$ & $0.5^{c}$ & & $0.1-5$ \\
\hline $\mathrm{Cd}$ & nd & nd & $0.1(0.05-0.2)$ & $1.0^{\mathrm{d}}$ & 1 & 2 \\
\hline
\end{tabular}

${ }^{a} \mathrm{~J} 1$ juveniles, 1-month-age; J2 juveniles, 3.5-month-age, ${ }^{\mathrm{b}}$ Concentration data are presented as mean (range); Wet weight concentration of heavy metals was calculated using the moisture content determined in present study of $96.5 \%, 93.4 \%$, and $84.5 \%$, respectively, ${ }^{\mathrm{c}}$ Maximum Levels of Contaminants in Foods, promulgated by Ministry of Health, China, 2005, ${ }^{\mathrm{d}}$ Residue Limit of Toxic Substances in Nuisanceless Foods and Aquatic Products, promulgated by Ministry of Agriculture, China, $2006,{ }^{\mathrm{e}}$ Setting maximum levels for certain contaminants in foodstuffs, promulgated by Commission Regulation, European Communities, $2001,{ }^{\mathrm{f}}$ Compilation of legal limits for hazardous substances in fish and fishery products, promulgated by FAO, 1983, nd, not detected.

( $0.5 \mu \mathrm{g} / \mathrm{g}$ wet weight), but was within the range of FAO (0.1-5 $\mu \mathrm{g} / \mathrm{g}$ wet weight). These results suggest that the background residue concentrations of heavy metals and toxic elements in our artificially produced juvenile mussels were low, and suitable to be used as the bioindicators for the corresponding elements by wild transplantation or laboratory exposure study. The gravid adults were collected from the Taihu Lake and held in the pond at the NFC for 1 year. The high level of As in the adults indicated that these mussels, even living in farmed habitats for a long period, may not be suitable for wild transplantation to monitor the As pollution.

\section{ACKNOWLEDGEMENTS}

This work was supported by the National Natural Science Foundation of China (Grant No.31072214) and the Ministry of Personnel of China (Grant No. 2-115084), and Jiangsu innovative experiment project for postgraduate students (2010CB429000). The authors would like to thank Dr. Ning Wang (Columbia Environmental Research Center) for critically reading and helping to improve the manuscript.

\section{REFERENCES}

Andral, B., H. Thebault and P. Boissery 2007 Monitoring chemical contamination levels in the Mediterranean based on the use of mussel caging. Rapp. Comm. int. MerMédit., 38: 226

Andral, B., J. Y. Stanisiere, D. Sauzade, E. Damier, H. Thebault, F. Galgani and P. Boissery 2004 Monitoring chemical contamination levels in the Mediterranean based on the use of mussel caging. Mar. Pollut. Bull., 49: 412-704

Belitz, H. D., W. Grosch and P. Schieberle 2009 Food Chemistry, 4th ed., Springer-Verlag, Berlin Heidelberg (Germany)

Bian, X., H. Liu, J. Gan, R. Li and J. Yang 2009 HCH and DDT residues in bivalves Anodonta woodiana from the Taihu lake, China. Arch. Environ. Contam. Toxicol., 56: 67-76

Christian, A. D. and B. N. Smith 2004 Trophic position and potential food sources of 2 species of unionid bivalves (Mollusca: Unionidae) in 2 small Ohio streams. J. N. Am. Benthol. Soc., 23: $101-113$

Cope, W. G., R. B. Bringolf, D. B. Buchwalter, T. J. Newton, C. G. Ingersoll, N. Wang, T. Augspurger, F. J. Dwyer, M. C. Barnhart, R. J. Neves and E. Hammer 2008 Differential exposure, duration, and sensitivity of unionoidean bivalve life stages to envi- ronmental contaminants. J. N. Am. Benthol. Soc., 27: 451-462 Cravo, A., M. J. Bebianno and P. Foster 2004 Partitioning of trace metals between soft tissues and shells of Patella aspera. Environ. Int., 30: 87-98

Dudgeon, D. and B. Morton 1983 The population dynamics and sexual strategy of Anodonta woodiana (Bivalvia: Unionacea) in Plover Cove Reservoir, Hong Kong. J. Zool. Lond., 201: 161183

Dudgeon, D. and B. Morton 1984 Site selection and attachment duration of Anodonta woodiana (Bivalvia:Unionacea) glochidia on fish hosts. J. Zool. Lond., 204: 355-362

Ferrington, J. W., E. D. Goldberg, R. W. Risebrough, J. H. Martin and V. F. Boven 1983 U.S. Mussel Watch 1976-1978. An overview of the trace metal, DDT, PCB, hydrocarbon and artificial radionuclide data. Environ. Sci. Technol., 17: 490-496

Fisher, G. R. and R. V. Dimock 2002 Morphological and molecular changes during metamorphosis in Utterbackia imbecillis (Bivalvia: Unionidae). J. Mollus. Stud., 6: 159-164

Goldberg, E. D. 1975 The Mussel Watch - a first step in global marine monitoring. Mar. Pollut. Bull., 6: 111

Haag, W. R. and M. L. Warren Jr 1999 Mantle displays of freshwater mussels elicit attacks from fish. Freshwater Biol., 42 $35-40$

Hédouin, L., O. Pringault, M. Metian, P. Bustamante and M. Warnau 2007 Nickel bioaccumulation in bivalves from the New Caledonia lagoon: Seawater and food exposure. Chemosphere, 66: $1449-1457$

Jacob, D. E., A. L. Soldati, R. Wirth, J. Huth, U. Wehrmeister and W. Hofmeister 2008 Nanostructure, composition and mechanisms of bivalve shell growth. Geochim. Cosmochim. Acta., 72: $5401-5415$

Kovitvadhi, S., U. Kovitvadhi, P. Sawangwong, A. Thongpan and J. Machado 2007 Morphological development of the juvenile through to the adult in the freshwater pearl mussel, Hyriopsis (Limnoscapha) myersiana under artificial culture. Invertebr. Reprod. Dev., 50: 207-218

Kurnia, A. I., E. Purwanto and E. Mahajoeno 2010 Exposure copper heavy metal $(\mathrm{Cu})$ on freshwater mussel (Anodonta woodiana) and its relation to $\mathrm{Cu}$ and protein content in the body shell. Nusantara Bioscience, 2: 48-53

Liu, H., J. Yang and J. Gan 2010 Trace element accumulation in bivalve mussels Anodonta woodiana from Taihu Lake, China. Arch. Environ. Contam. Toxicol., 59: 593-601

Liu, J., B. Gu, J. Bian, S. Hu, X. Cheng, Q. Ke and H. Yan 2008 Antitumor activities of liposome-incorporated aqueous extracts of Anodonta woodiana (Lea, 1834). Eur. Food. Res. Technol., 227: 919-924

Metcalfe-Smith, J. L., R. H. Green and L. C. Grapentine 1996 Influence of biological factors on concentrations of metals in the tissues of freshwater mussels (Elliptio complanata and Lampsilis radiate radiata) from the St. Lawrence River. Can. 
J. Fish. Aquat. Sci., 53: 205-219

Naimo, T. J. 1995 A review of the effects of heavy metals on freshwater mussels. Ecotoxicology, 4: 341-362

Pernice, M., J. Boucher, R. Boucher-Rodoni, P. Joannot and P. Bustamante 2009 Comparative bioaccumulation of trace elements between Nautilus pompilius and Nautilus macromphalus (Cephalopoda: Nautiloidea) from Vanuatu and New Caledonia. Ecotox. Enviro. Safe., 72: 365-371

Pynnönen, K. 1991 Accumulation of ${ }^{45} \mathrm{Ca}$ in the freshwater Unionids Anodonta anatina and Unio turnidus, as influenced by water hardness, protons, and aluminum. J. Exp. Zool., 260: 18-27

Ravera, O., P. R. Trincherini, G. M. Beone and B. Maiolini 2005 The trend from 1934 to 2001 of metal concentrations in bivalve shells (Unio pictorum) from two small lakes: Lake Levico and Lake Caldonazzo (Trento Province, Northern Italy). J. Limnol., 64: $113-118$

Ravera, O., G. M. Beone, R. Cenci and P. Lodigiani 2003b Metal concentrations in Unio pictorum mancus (Mollusca, Lamellibranchia) from of 12 Northern Italian lakes in relation to their trophic level. J. Limnol., 62: 121-138

Ravera, O., R. Cenci, G. M. Beone, M. Dantas and P. Lodigiani 2003a Trace element concentrations in freshwater mussels and macrophytes as related to those in their environment. J. Limnol., 62: $61-70$

Reimer, P. S. 1999 Environmental effects of manganese and proposed freshwater guidelines to protect aquatic life in British Columbia. Master of Science Thesis. University of British Columbia, Vancouver (Canada)

Scanes, P. R. and A. C. Roach 1999 Determining natural 'background' concentrations of trace metals in oysters from New South Wales, Australia. Environ. Pollut., 105: 437-446

Schwartz, M. L. and R. V. Dimock 2001 Ultrastructural evidence for nutritional exchange between brooding unionid mussels and their glochidia larvae. Invertebr. Biol., 120: 227-236

Tanabe, S. and A. Subramanian 2006 Bioindicators of POPS: Monitoring in Developing Countries. Kyoto University Press, Kyoto (Japan)

Usero, J., J. Morillo and I. Gracia 2005 Heavy metal concentrations in molluscs from the Atlantic coast of southern Spain.
Chemosphere, 59: 1175-1181

Wang, W. and N. S. Fisher 1996 Assimilation of trace elements and carbon by the mussel Mytilus edulis: Effects of food composition. Limnol. Oceanogr., 41: 197-207

Wang, W. and N. S. Fisher 1999a Assimilation efficiencies of chemical contaminants in aquatic invertebrates: a synthesis. Environ. Toxicol. Chem., 18: 2034-2045

Wang, W. and N. S. Fisher 1999b Delineating metal accumulation pathways for marine invertebrates. Sci. Total Environ., 237/238: $459-472$

Watters, G. T. 1997 A synthesis and review of the expanding range of the Asian freshwater mussel Anodonta woodiana (Lea,1834) (Bivalvia: Unionidae). Veliger, 40: 152-156

Watters, G. T. 2007 A brief look at freshwater mussel (Unionacea) biology. In "Freshwater bivalve ecotoxicology", ed. by J. L. Farris and J. H. Van Hassel. CRC Press, Boca Raton, Florida, and SETAC Press, Pensacola, Florida, USA, pp. 51-64

Weiss, I. M., N. Tuross, L. Addadi and S. Weiner 2002 Mollusc larva shell formation: amorphous calcium carbonate is a precursor phase for aragonite. J. Exp. Zool., 293: 478-491

Wenchuan, Q., M. Dickman and W. Sumin 2001 Multivariate analysis of heavy metal and nutrient concentrationsin sediments of Taihu Lake, China. Hydrobiologia, 450: 83-89

Williams, J. D., M. L. Warren, K. S. Cummings, J. L. Harris and R. J. Neves 1993 Conservation Status of freshwater mussels of the United States and Canada. Fisheries, 18: 6-22

Yang, J., H. Harino, H. Liu and N. Miyazaki 2008 Monitoring the organotin contamination in the Taihu lake of China by bivalve mussel Anodonta woodiana. Bull. Environ. Contam. Toxicol., 81: 164-168

Yang, J., H. Wang, H. Zhu, X. Gong and R.Yu 2005 Bioaccumulation of heavy metals in Anodonta woodiana from Wulihu area of Taihu Lake. Resour. Environ. Yangtze Basin, 14: 362-366 (in Chinese with English abstract)

Ye, S., J. Yang, H. Liu and Y. Oshima 2011 Use of elemental fingerprint analysis to identify localities of collection for the large icefish Protosalanx chinensis in Taihu Lake, China. J. Fac. Agr Kyushu Univ., 56: 41-45 